\title{
Alfred de Musset, A quoi rêvent les jeunes filles et autres pièces
}

Valentina Ponzetto

\section{Q OpenEdition}

1 Journals

\section{Edizione digitale}

URL: http://journals.openedition.org/studifrancesi/34932

DOI: 10.4000/studifrancesi.34932

ISSN: 2421-5856

\section{Editore}

Rosenberg \& Sellier

\section{Edizione cartacea}

Data di pubblicazione: 1 novembre 2005

Paginazione: 435

ISSN: 0039-2944

\section{Notizia bibliografica digitale}

Valentina Ponzetto, «Alfred de Musset, A quoi rêvent les jeunes filles et autres pièces», Studi Francesi

[Online], 146 (XLIX | II) | 2005, online dal 30 novembre 2015, consultato il 21 avril 2021. URL: http:// journals.openedition.org/studifrancesi/34932 ; DOI: https://doi.org/10.4000/studifrancesi.34932

Questo documento è stato generato automaticamente il 21 avril 2021.

\section{(c) (i) (9)}

Studi Francesi è distribuita con Licenza Creative Commons Attribuzione - Non commerciale - Non opere derivate 4.0 Internazionale. 


\title{
Alfred de Musset, A quoi rêvent les jeunes filles et autres pièces
}

\author{
Valentina Ponzetto
}

\section{NOTIZIA}

ALFRED DE MUSSET, A quoi rêvent les jeunes filles et autres pièces, édition présentée par Frank LESTRINGANT, Paris, Librio, 2004, pp. 126.

1 Nella più agile ed economica veste offerta dalla scena editoriale francese, senza note né dossier critico, Librio pubblica tre pièces brevi e giovanili di Musset: A quoi rêvent les jeunes filles, La Nuit vénitienne e Les Marrons du feu. Fra verso e prosa, prime ingenuità dell'innamoramento e crimini passionali, amanti timidi o eloquenti, e donne imprevedibili e volitive, in un'Italia immaginaria e irreale o «où l'on voudra», il lettore ritroverà tutta l'audacia, la libertà e la seduzione del miglior teatro romantico. La breve introduzione di Frank Lestringant, sposando la concisione e la leggerezza ironica dei testi, non rinuncia a presentare i temi e le caratteristiche di un teatro che contiene già in potenza tutti gli elementi della più matura drammaturgia mussettiana. 